\title{
Nooit weer nie? 'n Teologies-etiese beoordeling van die idees oor politieke vryheid in Suid-Afrika sedert 1899
}

\author{
J.M. Vorster \\ Skool vir Kerkwetenskappe \\ Potchefstroomse Universiteit vir $\mathrm{CHO}$ \\ POTCHEFSTROOM \\ E-pos:
}

\begin{abstract}
Never again? A theological-ethical evaluation of ideas about political freedom in South Africa since 1899

Various conflicting concepts of political freedom and the process of liberation have played a major part in South African society over the past century. These concepts have inherently been influenced by theological-ethical guidelines given by prominent Christian leaders and churches. This article focuses on the conflicting concepts of freedom as they were defined from a theological-ethical perspective in the old republics of Transvaal and the Orange Free State during the Anglo-Boer war which started in 1899, the apartheid society since 1948 and in the Black Liberation struggle which culminated in the democracy of 1994. In every instance the theological-ethical presuppositions used in the formulation of each particular concept of freedom are defined and analysed. In conclusion attention is paid to the state of freedom in South Africa in 2000 and the church's responsibility to contribute to the development of an ethos of human rights from an ecumenical theological-ethical foundation.
\end{abstract}

\section{Inleiding}

By die oorhandiging van die verslag van die Waarheids- en Versoeningskomissie aan die Staatspresident van Suid-Afrika op 29 Oktober 1998 het die voorsitter van die kommissie, aartsbiskop D. Tutu gesê: "Nooit weer nie". Daarmee het hy bedoel dat die verdrukking wat mense in Suid-Afrika sedert die kolonisasie van 1652 geken het, nooit weer mag plaasvind nie. $\mathrm{Na}$ die verkiesing en aanvaarding van die grondwet van 1996 het die Suid-Afrikaanse nasie uit 'n situasie beweeg waar sommitge mense bevoordeel is en ander verdruk is. Hiermee is vryheid in beginsel gevestig vir alle burgers van die land. 
Ten spyte van die onderdrukking van verskeie gemeenskappe in die moderne geskiedenis van Suid-Afrika, was die vryheidsgees tog deurgaans vaardig. Die Christendom en by name die Protestantse Christendom was die dominante godsdiens. Vryheid is in verskillende periodes gedefinieer vanuit definitiewe Christelike, teologies-etiese beginsels. Die vraag is: watter rol het die teologies-etiese beginsels oor politieke vryheid in die vryheidsbeskouinge in Suid-Afrika sedert 1899 gespeel, en waarom het die toepassing van hierdie beginsels nie die sosiale onreg, waarvan die Waarheids- en Versoeningskomissie in hulle verslag melding gemaak het, verhinder nie?

Die sentraal-teoretiese argument van hierdie artikel kan saamgevat word in die volgende stelling: die dominante vryheidsbeskouinge in Suid-Afrika sedert 1899 is wesenlik beïnvloed deur teologies-etiese voorveronderstellings wat in sekere opsigte in kerklike isolasie geformuleer is en in ander opsigte sekulêr-ideologies beredeneer is. Hierdie voorveronderstellinge het gelei tot verskeie vorme van diskriminasie en verdrukking in die naam van die Christelike geloof. Die vernaamste vryheidsbeskouings soos dit oor die afgelope eeu in die Suid-Afrikaanse geskiedenis gefigureer het, word onder die soeklig gestel en daar word gelet op die invloed van die standpunte van invloedryke leiers en organisasies. Die vryheidsbeskouings wat ondersoek word, is dié rondom die aanleiding tot die Anglo-Boereoorlog in 1899, die aanloop en toepassing van apartheid onder leiding van die Nasionale Regering in 1948, die vryheidsbeskouing wat die koms van volledige demokrasie in Suid-Afrika in 1994 voorafgegaan het, en die moontlike scenario vir 2000 en verder. Om die verskillende beskouings histories te tipeer word die datums 1899, 1948 en 1994 as momente in die periodisering van hierdie ondersoek gebruik.

\section{Politieke vryheid in $\mathbf{1 8 9 9}$}

Die konstitusies van die Zuid-Afrikaansche Republiek (ZAR) en die Republiek van die Oranje-Vrijstaat (OVS) het in sekere opsigte die gees geadem van die konstitusionalisme van die negentiende eeu in Europa. Baie klem is in dié stroming gelê op die uitgangspunt dat die regering die meerderheid van die bevolking moet verteenwoordig en dat gesag uit die gemeenskap voortkom. Nieuwoudt (1966:71) sê hieroor die volgende: "Die onderliggende idee waarop die hele beskawing berus het, was dat elke gemeenskap 'n geskrewe grondwet moes verkry waarin die regte en pligte van die burgers enersyds en dié van die owerheid andersyds beskryf is". Hierdie konstitusionalisme was die kulminasie in daardie tyd van die demokratisering van die staat wat sedert die werk van Locke (1632-1704) in aansien toegeneem het. In sy invloedryke Treatises on government het Locke gestel dat die mens natuurlike regte het tot lewe, vryheid en eiendom. Om hierdie regte te verseker moet die owerheid 
saamgestel word deur middel van die stem van die onderdaan (Van der Vyver, 1975:1). Die meerderheid moet regeer en wanneer die wil van die meerderheid nie uitgevoer word nie, het onderdane die reg van rewolusie (Walker, 1992:571). Hierdie elemente het ook inslag gevind in die twee republieke met hulle kragtige onafhanklikheidsin.

Oor die konstitusies van die twee Boererepublieke sê Nieuwoudt (1966:72): "Maar bowenal was die konstitusies 'n uitdrukking van die wil van die volk, 'n volk met 'n diepgaande vryheidsin wat deel wou hê aan en ook die verantwoordelikheid wou aanvaar vir sy eie owerheidsinstellinge". Die konstitusie van die OVS is in 1854 aanvaar en het daarna nie noemenswaardige veranderinge ondergaan nie. Die konstitusie van die ZAR is in 1858 aanvaar en het verskeie wysigings ondergaan. Albei konstitusies het egter gesentreer in die vryheid van die volk.

Artikel 8 van die grondwet van die ZAR het gelui:

Het volk eischt de meest mogelijke maatschappelijke vrijheid en verwacht die van het behoud van zijn godsdienstig geloof; van de nakoming zijner verbintenissen; van zijne ondergeschiktheid aan wet, orde en regt, en de handhaving van dezelve. Het volk laat de uitbreiding van het Evangelium toe onder de heidenen, onder bepaalde voorzorgen tegen gebrek en misleiding.

Daarop volg in artikel 9: "Het volk wil geene gelijkstelling van gekleurden met blanke ingezetenen toestaan, noch in Kerk noch in Staat' (ZAR, 1918:364). 1

Tog was daar in die konstitusie van die ZAR 'n interessante anomalie as dit gesien word in die lig van die demokratiese beweging in Europa. Stemreg was slegs vir blanke manspersone wat lidmate was van die Protestantse Kerke. ${ }^{2}$ Wet 13/1891 artikel 2 het ook bepaal dat slegs blankes as stemgeregtigde burgers vir die verkiesing van die staatspresident aangeteken kon word (Vivier, 1970:6). Die demokrasie was dus beperk in kerklike, etniese en geslagtelike sin. Laasgenoemde was wel eie aan die betrokke tyd. Die vraag is egter: waarom hierdie teenstrydigheid in die lig van die gees van die konstitusionalisme?

1 Die woorde in kursief is in 1889 weggelaat (Eybers, 1918:364).

2 Cuthbertson (1994:152) beweer ten onregte dat die grondwet stemreg slegs vir manspersone uit die Afrikaanse gereformeerde kerke gereserveer het. Hierdie foutiewe aanname beïnvloed sy beredenering en bevinding dat die Boere 'n "volkseksklusiwistiese benadering" tot die grondwet gehad het. Sy argumentasie laat nie reg geskied aan die feit dat hulle die vryheid in die grondwet nie primêr wou beredeneer vanuit die volksmotief nie, maar vanuit hulle Calvinistiese beskouing oor die staat en gesag. 
Volgens Nieuwoudt (1966:89) lê die teenstrydigheid daarin dat die Boere hulle idees van vryheid en regte - in teenstelling met die Franse rewolusionêres - nie op die natuurregte gebaseer het nie, maar op die Calvinistiese siening van maatskappy en staat wat inhou dat alle gesag van die soewereine God af kom. Hierdie stelling is gedeeltelik korrek maar verdien verdere kritiese bespreking.

Nieuwoudt se siening is korrek in die sin dat die Calvinisme in navolging van Calvyn en die gereformeerde belydenisskrifte, die soewereiniteit van God met betrekking tot die inrigting van die staat as uitgangspunt beklemtoon het. Die beginsel het duidelik 'n belangrike rol in die denke onderliggend aan die grondwette gespeel. Wat egter, naas dit wat Nieuwoudt sê, ook in berekening gebring moet word is die feit dat Calvyn self ook die uitdrukking "natuurreg" (lex naturae) in positiewe sin gebruik het. Calvyn het gesê dat die wet van God meer is as net die Tien Gebooie. In sy inleiding tot die Tien Gebooie praat hy van die wet wat aan alle mense gegee is (Calvyn. 1957. Inst II:VII:1:317). In dieselfde bespreking verwys hy na dié wet as die natuurwet. Hy sê verder in sy kommentaar op Romeine 2:14-15 dat 'n indruk van geregtigheid in elke mens ingegraveer is (Calvyn, 1864:48). Dieselfde idees is uitgewerk in sy preke oor Deuteronomium 4:44-6:4 en 19:14-15.3

Die regte wat in die grondwette van die twee republieke sterk beklemtoon is, staan dus waarskynlik nie vry van die konsep van natuurreg wat verkeerdelik net aan die gees van die Franse Rewolusie toegedig word nie. Calvyn het ook nie beperkings in sy siening van stemreg ingebou nie (Witte, 1996:376). Die gees en inhoud van die konstitusies kan dus nie sonder meer aan die Calvinisme toegedig word nie. 'n Ontleding van die vryheidsbegrip in die konstitusies van die twee republieke en soos dit verduidelik is in die toesprake van presidente Kruger en Steyn dui aan dat die begrip 'n ander unieke teologies-etiese onderbou gehad het.

Die vryheid van die volk is beredeneer in die lig van die Eksodusmotief van die Ou Testament. Die Voortrekkers is geïdentifiseer met die volk Israel van die Ou Testament en die volgende parallel is getrek: soos God Israel uit die slawerny van Egipte uitgelei het, so het hy die Voortrekkers uitgelei uit die slawerny van die Britse besetting van die Kaapkolonie. Pres. Paul Kruger het hierdie opvatting verwoord in sy toesprake by

3 Calvyn se siening oor die natuurreg is deeglik uitgewerk deur Bohatec (1961:19). Hy beskryf die begrip soos dit deur Calvyn gebruik is soos volg: "Die lex naturae ist vornehmlich der Inbegriff der praktischen, dem Menschengeist angeborenen rechtlichen und sittlichen Prinzipien (iustitiae ac rectitudinis conceptiones) die die Griechen als proletheis bezeichnet haben". Kyk ook Vorster (1999:209-220). 
Paardekraal. In die toespraak van 16 Desember 1896 roep hy almal op om te dink aan God se werk in die Ou Verbond. Hy het die verloop van die Ou Verbond verduidelik en gewys op die feit dat God aan sy Verbond getrou gebly het. Dan pas hy dit toe op die Boerevolk (ou inwoners):

$U$ ganse skaar wat hier vergader is om die gedenkteken wat vir ons en ons nageslag as 'n blywende monument opgerig is; let op wat daar geskrywe staan, op die feite, sodat u weet wat God gedoen het om ons te verlos en ons kan vashou aan die gedagte dat Hy sy volk verlos het met sy almagtige hand, opdat ons getrou mag wees aan ons gelofte om Hom te dien en ander daartoe op te wek (Kruger, 1952b:101; vertaling deur J.S. du Plessis; kyk ook Rompel, 1902:5).

Die invloedryke gereformeerde teoloog en digter J.D. du Toit (Totius) verwys met instemming na 'n telegram wat Kruger op 20 Junie 1900 aan sy krygsoffisiere gestuur het en waarin die president verwys na Israel se verlossing en dit dan regstreeks so op die Boerevolk roepas: "Dieselfde God het ons uitgelei met wonders en mirakels en aan ons ons vryheid gegee". Die president sê dan voorts; "En dink u dat God sy saak, wat hy eenmaal begin het sal laat vaar? Nee, Hy sal dit nie laat vaar nie" (Du Toit, 1977:23). Hieruit is dit duidelik dat hy die bevryding van Israel in die Ou Testament op eksemplariese wyse toepas op die Voortrekkers en hulle nasate asook op die onafhanklikheid van die twee republieke.

Minder eksplisiet, maar tog sigbaar was dieselfde sentimente by president M.T. Steyn van die OVS teenwoordig (Steyn, 1953:84). Vir Kruger en Steyn was die onafhanklikheid van die ZAR en die OVS 'n kosbare kleinood. In sy verkiesingsmanifes vir die 1888 presidentsverkiesing sê Kruger byvoorbeeld:

Ek voel dat ek 'n vloek op my sal haal as die onafhanklikheid en vryheid deur my geskend word. Daardie eersgeboortereg van die volk moet as 'n dierbare kleinood bewaar word. As ons die eersgeboortereg nie beskerm nie; as ons soos Esau wat syne verkoop het handel, sal net soos in sy geval God sy seën van ons afwend (Kruger, 1952a:32).

In die beredenering van die vryheid van die Boerevolk het die Bybelse begrippe oor die bevryding van Israel dus 'n beduidende rol gespeel.

Tog is die beredenering van die vryheid in 'n ander sin nie losgemaak van die sekulêre ideologiese idees van die negentiende eeu nie. Hierdie feit blyk uit die beredenering van die vryheid van die swart mense. Hoe het die grondwette oor die vryheid van die swart mense geoordeel? Hierdie saak is op 'n eiesoortige wyse in die grondwette betrek. Nieuwoudt (1966:89) sê: 
Die Voortrekkers en Boere het aanvaar dat die blanke die draer van die beskawing na swart Afrika is. In die onderskeie wette word die idee ook telkens na vore gebring. So bepaal die grondwet van die Suid-Afrikaanse Republiek duidelik dat die Evangelie oorgedra moet word en dat daar geen gelykstelling tussen blanke en gekleurde mag plaasvind nie. ' $n$ Soort voogdyskap is oor die nie-blanke aanvaar waardeur hy beskerm kan word; daarom is geen slawerny geduld nie. In die praktyk het hierdie idees uiting gevind in 'n soort segregasiebeleid waarin nie net die blanke beskawing beveilig is nie maar ook die nie-blanke beskerm is.

Nieuwoudt stel dit in positiewe sin, waarskynlik omdat sy insiggewende artikel geskryf is in 1966 - in die hoogbloei van die republikeinse gees van daardie tyd.

Die idee van blanke voogdyskap was egter tipies van die sekulêre politieke ideologie van die negentiende eeu. Die Fransman, De Goubineau, het in sy "Essay on the inequality of human races" die eerste poging aangewend om vanuit die filosofie 'n regverdiging van die prinsipiële ongelykheid van mense van verskillende "rasse" op te stel (Vorster, 1981:15). Hierdie beskouing is op politieke gebied gebruik as 'n regverdiging van kolonisasie en voogdyskap. Banton (1970:20) sê hieroor die volgende: "The idea that the Saxon people might be biologically superior to the Celts and Slaves and white races to black was seized upon, magnified and publizised, because it was convenient to those who held power in the Europe of that day." Hierdie standpunt word ook gehuldig deur Burns (1948:17). Blanke Europa het sy kolonisasie gebou op die "edele roeping" van die "hoëre Europese blanke kultuur" ten opsigte van die "laere swart kultuur". Die idee van ongelykheid en voogdyskap is dus vanuit die sekulêre denkwêreld van die negentiende eeu in die Bybel ingelees.

Die vryheidsgees, soos dit konstitusioneel geformuleer en Bybels beredeneer is, het hoog opgevlam in die republieke. Die maatskaplike omstandighede van die Boere het daartoe bygedra. Hulle was oortuig dat hulle politieke vryheid en onafhanklikheid deur verskeie faktore bedreig is. Hulle vryheid en onafhanklikheid is deur die Engelse kerke sterk afgewys en hierdie kerke het ook die Britse imperialisme gesanksioneer. Verder is die vryheidstrewe van die Boere deur die Engelse kerke bedreig met bepaalde teologies-missiologiese begronding. Prediking in die Engelse kerke en artikels in kerklike tydskrifte toon aan dat dié kerke die argument gebruik het dat 'n Britse oorwinning groter geregtigheid vir die swart mense sal meebring. Veral die Anglikaanse en Metodistekerke het aan hierdie argument stukrag gegee (Cuthbertson, 1994:154). 
Tweedens het die Boere bedreig gevoel deur die swart mense. Die Britte het vir eie politieke gewin 'n wig probeer indryf tussen die Boere en die swart mense. Cuthbertson (1994:151) toon aan hoe die Kgatla, Pedi, Ndebele en Zoeloes deur die Britte aangemoedig en ook bewapen is om die Boere aan te val. Hy dui, met betroubare dokumentêre bewys, verskeie geleenthede aan waar sodanige aanvalle uitgevoer is. Vir die Boere was dit 'n bedreiging van hulle vryheid. Die sogenaamde uitlanders, wat na die ontdekking van goud na die ZAR gekom het, was vir die Boere 'n derde bedreiging. Oor die Boere se siening van die uitlanders en die beleid wat teenoor hulle gevolg is, het baie vakliteratuur die lig gesien. Oor geen aspek van Kruger se openbare optrede is soveel geskryf as oor hierdie een nie en die beoordeling daarvan word gedoen vanuit verskillende gesigspunte (De Klerk, 1969:156). Hoe dit ook al beoordeel word, die feit bly staan dat die uitlanderkwessie saam met die ander sosio-maatskaplike vraagstukke die konteks gevorm het waarbinne die Boere hulle vryheidsin gedefinieer en beleef het.

Die vryheidsbegrip in die twee republieke is dus in 1899 teologies-eties geregverdig met die Eksodusmotief van die Ou Testament, en ondersteun deur die idee van blanke voogdyskap en die idee dat die vryheid tot die Boerevolk beperk was. Hierdie vryheid is konstitusioneel verskans. Die uitslag van die Anglo-Boereoorlog en die Uniewording onder koloniale Britse bewind was vir die Afrikanervolk (soos die begrip in die omgangstaal al hoe meer gebruik is) 'n verlies aan vryheid. Hierdie verlies het gelei tot 'n nasionalisme wat gerig was op die herwinning van vryheid vir die volk in 'n verenigde Suid-Afrika. Die verlies aan vryheid is beleef as verdrukking. Vryheid het verdrukking geword en die stryd daarteen moes uitloop op die konflikte wat in die dekades daarna gevolg het.

\section{Politieke vryheid in $\mathbf{1 9 4 8}$}

In die vryheidstrewe van die Afrikaner na die Anglo-Boereoorlog het verskeie motiewe 'n rol gespeel, maar soos in die doel van die artikel aangedui is, word hier net aandag gegee aan die teologies-etiese onderbou van die ontwikkelende vryheidsbegrip in hierdie periode. Belangrike eksponente van hierdie onderbou was die teoloog en digter, Totius, en die politieke leiers Malan en Verwoerd. Ander het wel ook 'n rol gespeel, maar hierdie figure kan beskou word as van die belangrikste argitekte van die vryheidsbegrip wat gelei het tot die oorname van die Nasionale Party in 1948 en die beleid van apartheid en afsonderlike ontwikkeling wat daarop gevolg het.

Totius het met sy geskrifte die gees van die vryheid, soos beredeneer deur Kruger, lewend gehou. So skryf hy in 1943: 
Kruger se nasie het herlewe. Om maar een ding te noem. Uit die oorlog, as motief, is ons taal as skryf- en volkstaal gebore. En daarmee is in beginsel alles gewen. Uit die leed van die stryder en van vrou en kind in die konsentrasiekampe - uit leed is die lied gebore, en uit die lied die taal, en uit die taal die nasie. Kruger en sy volk het skynbaar ondergegaan. Maar die volk het herrys en met hulle saam die onverganklike beeld van die staatsman (Du Toit, 1977a:19).

Met sy pakkende gedigte het Totius die volksbesef en die vryheidgees wakker gehou. In hierdie verband kan gewys word op sy treffende: "By die monument" (1977:13); "Trekkerswee" (Du Toit, 1977:133); "Uit donker Afrika" (Du Toit, 1977:255) en "Skemering" (Du Toit, 1977:313). Sy bekende "Vergewe en vergeet" na aanleiding van Deuteronomium 4:9 het die gees van nasionalisme op skole en volksfeeste aangevuur. Sy toespraak gelewer op die "Volkskongres oor die rassebeleid" in 1944 met die titel "Die godsdienstige grondslag van ons rassebeleid" was egter die duidelikste voorbeeld van hoe teologies-etiese motiewe gebruik is om die vryheid van die Afrikaner deur 'n beleid van "rassesegregasie" te waarborg (Du Toit, 1977:330).

Totius begin sy toespraak deur te sê dat die hele Bybelse openbaring 'n bewys bied dat segregasie in ooreenstemming is met die uitsprake van die Heilige Skrif. Dan gaan hy voort om die voortgang van die openbaring met betrekking tot hierdie beskouing te behandel. In sy vertrekpunt beskryf hy God as die groot skeidingmaker (Du Toit, 1977a:330). By wyse van verskeie motiewe werk hy hierdie beskouing dan verder uit. Eerstens wys hy op die skeppingsmotief. God as die "Hammabdil" bring skeiding tussen lig en duisternis, tussen waters en waters, tussen lig en duisternis, tussen mens en dier, ensovoorts. Hierdie optrede van God wys dan dat hy 'n kloof vestig en dat daar oor die kloof geen brug is nie. Die konsekwensie van sy standpunt is dat God mense in verskillende rasse geskape het en dat daar tussen die rasse geen brug kan wees op sosiale en politiek gebied nie. Hy volg die skeppingsmotief op met die Babelmotief (Du Toit, 1977:332). Hy sê dat die mensheid by Babel 'n sondige eenheidstrewe gehad het. God as die skeidingmaker tree dan weer op deur die mensheid in verskillende volke te verdeel. Sonder deeglike argumentasie betrek hy dan, met 'n sitaat van Kuyper, die Groot Trek binne hierdie motief en sê dat "die Kaapse Boere die bestel van God sou weerstaan het as hulle nie uitgetrek het nie ..." (Du Toit, 1977:332).

Die Babelmotief word opgevolg met die eskatalogiese motief: nasies moet hulleself handhaaf tot aan die voleinding toe. Volgens Totius leer Openbaring 21:24 dat die nasies nog in die Nuwe Jerusalem sal 
voortbestaan. In die lig hiervan moet alle assimilasie van blank en gekleurd afgewys word. Die Babelgedagtes wat telkens in die geskiedenis opduik, is anti-Christelike humaniteitsgedagtes en die vorming van wêreldryke word in die Bybel met diere vergelyk (Du Toit, 1977:333). Enkele sinne word daarna gewy aan die Christusmotief. Mense word geestelik een in Christus, maar die aardse onderskeidinge bly bestaan (Du Toit, 1977:334). Hierdie Christusmotief lei hom dan ook logies na die ekklesiologiese motief waarin hy betoog dat daar 'n kerk vir elke rassegroep moet wees. Die "naturel" moet in die Christelike kerk sy eie tipe verteenwoordig. Die konklusie waartoe hy kom nadat hy hierdie motiewe aan die orde gestel het, is dat "wat God geskei het, mag geen mens saamvoeg nie". Assimilasie is liberalisties en humanisties.

Hierdie poging van Totius om apartheid Bybels te regverdig het wye aanklank in die Afrikaanse politiek en volkslewe gevind (kyk hieroor Van Wyk, 1993:39). Apartheid ten einde die blanke vryheid teen die "swart gevaar" te waarborg is op grond van hierdie soort standpunte teologieseties gelegitimeer en deur politici aangewend om die apartheidsbeleid te bemark. ' $n$ Beoordeling van die standpunte van Totius bring ernstige vrae oor sy voorveronderstellings, hermeneutiek en Skrifgebruik na vore, asook sy negering van die beskouinge hieroor in die gereformeerde tradisie sedert Calvyn. Die belangrikste kritiekpunt is egter die feit dat die leer oor die versoening en die sosiale implikasies daarvan nie in die Christusmotief deeglik uitgewerk is nie. Sy voorstelling van God as skeidingmaker druis in teen die hele essensie van die versoening in Christus. Die apartheidsmensbeskouing soos dit hiervandaan in die volkslewe van die Afrikaner en in die drie Afrikaanse Kerke ontwikkel het, is reeds deur Kinghorn (1986:47) en Van Wyk (1993:41) behandel en daarom word dit nie verder aan die orde gestel nie.

Die ideaal van vryheid vir die Afrikaner in 'n verenigde Suid-Afrika is vroeg in die eeu op politieke vlak uitgespel. In sy beroemde toespraak in 1918 het D.F. Malan, teoloog en politikus, die onafhanklikheid van SuidAfrika bepleit. Hy het gesê dat die Afrikanervolk in sy geheel gesien, republikeins is, en dat hulle nie net 'n republiek wil hê nie, maar "'n regeringsvorm ... waardeur bedoel word dat die vrye volkskeuse te alle tye die inherente en onvervreembare reg van Suid-Afrika sal wees" (Malan, 1964b:23). Die politieke vryheidsideaal was duidelik die beliggaming van die teologies-etiese onderbou van die vryheidsgedagte soos dit vanaf Kruger oorgedra is. Malan het dit self verwoord in sy toespraak op 16 Desember 1938 by Bloedrivier (Malan, 1964e:121). Jare later het hy die Afrikaner vergelyk met die volk Israel in ballingskap en gesê dat soos Israel daaraan herinner is om Jerusalem nooit te vergeet 
nie, die Afrikaner ook altyd herinner moet word aan die republiek van Kruger ten einde dit weer te laat realiseer (Malan, 1964a:87).

Die vrye volkskeuse wat hy en die Nasionale Party nagestreef het was, naas vryheid van Britse oorheersing, ook 'n keuse vir apartheid. Die voogdyskapsgedagte was diep in hierdie beskouing ingebou hoewel die gedagte van ongelykheid nie eintlik by Malan voorgekom het nie. Met die bewindsaanvaarding in 1948 het Malan gesê dat apartheid nie die karikatuur is wat so dikwels daarvan gemaak is nie. Dit beteken vir die nie-blankes die opbou van groter selfstandigheid en van hulle gevoel van selfrespek sowel as die verskaffing van ruimer geleentheid vir vrye ontwikkeling ooreenkomstig hulle eie aard en vatbaarheid (Malan, 1964d:243). Wanneer hy gepraat het van die volk het hy kennelik slegs die blankes en, in meeste gevalle, die Afrikaners in die oog gehad. Ook hierin het die teologies-etiese sentimente soos verwoord deur Totius 'n duidelike rol gespeel (Malan, 1964c:252). Op teologies-etiese vlak is Malan se idees geregverdig deur invloedryke teoloë soos Groenewald, Hanekom, J.D. Vorster en Kritzinger (Kinghorn, 1986:86) en amptelik deur die drie Afrikaanse kerke. (Kyk ook Villa-Vicencio, 1988:22.) Die morele regverdiging van apartheid is ook op godsdienstige gronde geprogageer deur die latere redakteur van Die Kerkbode, die teoloog A.P. Treurnicht. Hy het hom beroep op Nederlandse teoloë soos Smeenk en Kuyper en die Suid-Afrikaanse teoloë Müller en Potgieter asook 'n sinodale dokument van die Gereformeerde Kerke in Suid-Afrika waarin die invloed van Totius baie sterk was (Treurnicht, 1975:12). Sy leiersposisies wat hy later in die regerende Nasionale Party en daarna as leier van die Konserwatiewe Party beklee het, getuig van die invloed wat hy onder Afrikaners gehad het. Hierdie leerstellings het Afrikaanse gereformeerdes se godsdienstig gefundeerde positiewe beskouing ten gunste van apartheid diepgaande beïnvloed (vgl. Vorster, 1998:475). Kritiese stemme teen die Bybelse fundering van apartheid het egter uitgegaan van Keet en Marais (De Gruchy, 1979:53).

$\mathrm{Na} 1948$ is die beleid van apartheid meer in besonderhede uitgewerk en is gepoog om dit sosiologies te fundeer. Steeds is dit egter gesien as die Christelike beleid teen die "liberalisme" se opvatting van rassesegregasie. Al hoe meer het die gedagte posgevat dat die vryheid van die Afrikaner verseker kan word met 'n beleid van algehele rasseskeiding en die uitfasering van die konsep van voogdyskap. In hierdie beredenering was die werk van Cronje, ' $n$ professor in Sosiologie aan die Universiteit van Pretoria, belangrik (Cronje, 1946:42). Op hierdie wyse is gepoog om hoër morele grond en 'n wetenskaplike fundering aan apartheid te gee. Die politieke vormgewing hiervan is gedoen deur H.F. Verwoerd, wat in die geskiedenis bekend staan as die argitek van apartheid (Kenney, 
1980:157). Hierdie beskrywing is egter oordrewe, gesien in die lig van die lang ontwikkeling van Afrikanervryheid, segregasie en blanke voogdyskap wat so lank deel was van die vryheidskonsep van die Afrikaner.

Verwoerd se bydrae was egter belangrik omdat hy 'n belangrike wending gebring het in die toepassing van die Nasionale regering se rassepolitiek. In sy deelname aan die debat oor die wetsontwerp ter bevordering van "Bantoe-selfbestuur" op 20 Mei 1959 het hy hom só uitgelaat oor die beleid van afsonderlike ontwikkeling, soos apartheid herdoop is:

Die Nasionale Party se standpunt is die van te strewe na 'n permanente blanke Suid-Afrika, watter gevaar dit ookal mag bedreig, met gereedheid tot die ontwikkeling van gebiede waarin die Bantoebeheer kan toeneem onder leiding van die Blanke as voog, en met die verstandhouding dat selfs al sou dit lei tot Bantoe-selfstandigheid, dit deur staatsmanswysheid beoog word om te sorg dat daardie ontwikkeling in so 'n gees en op so 'n wyse sal plaasvind dat vriendskap moontlik sal bly hoewel sonder dat die blanke ooit onder enige vorm van Bantoebeheer sal verkeer, hetsy in federale vorm of uniale vorm (Verwoerd, 1963:275).

Die skeiding van rasse is op alle gebiede deurgevoer en het nie net tuislande behels nie, maar ook stede, dorpe en alle maatskaplike en opvoedkundige instellings. Ook die kerk is deur wetgewing verplig om rasseskeiding toe te pas (Millard, 1994:267). Die bedoeling van afsonderlike ontwikkeling was om aparte vryheid vir die volke te vestig. Die klem het stelselmatig verskuif van ' $n$ rassebeleid na ' $n$ volkerebeleid. Ook hiervoor is teologies-etiese fundering uitgewerk veral uit die kringe van die Gereformeerde Kerke in Suid-Afrika (vgl. Du Plessis, 1963; Snyman, 1977; en Coetzee, 1965).

Die beleid van afsonderlike ontwikkeling het 'n hewige stryd op politieke en kerklike vlak tot gevolg gehad. Op politieke vlak het die toepassing van hierdie beleid gelei tot die internasionale isolasie van Suid-Afrika, ekonomiese sanksies en buitelandse ondersteuning van geweld teen die politieke bestel. Op kerklike gebied het dit gelei tot diepgaande skeuring tussen die kerke wat apartheid ondersteun het en dié wat daarteen was (De Gruchy, 1979:103; Millard, 1994:269). Die verset teen die stelsel het gelei tot veiligheidswetgewing en al hoe meer ander wette wat 'n kultuur van strukturele geweld en teengeweld tot gevolg gehad het.

Wat begin is as 'n strewe na vryheid vir die Afrikaner het gelei tot 'n sisteem van gelegaliseerde onreg teen $80 \%$ van die Suid-Afrikaanse bevolking. Die konsekwente deurvoer van die vryheid van die Afrikaner op grond van teologies-etiese grondmotiewe het, soos in 1899, gelei tot 
onvryheid vir ander. Vryheid het sy teenpool verdrukking opgeroep. Die verdrukking het op sy beurt weer ' $n$ intense nasionalistiese vryheidstrewe by die swart bevolking tot gevolg gehad. Die botsende vryheidstrewes het Suid-Afrika onderwerp aan die konflik wat die dekades sestig tot negentig gekenmerk het. Die konflik word duidelik aan die lig gebring in die verslag van die Waarheids- en Versoeningskommissie (WVK, 1998). Die swart vryheidstrewe het egter ook sy teologies-etiese onderbou gehad. Hieraan word vervolgens aandag gegee.

\section{Politieke vryheid in 1994}

Die vryheidskonsep van die swart nasionalistiese vryheidsbewegings is duidelik uitgedruk in die "Freedom Charter" van 1955. Dit lui:

We, the people of South Africa, declare for all our country and the world to know: That South Africa belongs to all who live in it, black and white, and that no government can justly claim authority unless it is based on the will of all the people; that our people have been robbed of their birthright to land, liberty and peace by a form of government founded on injustice and inequality; that our country will never be prosperous or free until all our people live in brotherhood, enjoying equal rights and opportunities; that only a democratic state, based on the will of the people, can secure to all their birthrights without distinction of colour, race, sex or belief; and therefore, we the people of South Africa, black and white together - equals, countrymen, and brothers - adopt this Freedom Charter. And we pledge ourselves to strive together, sparing neither strength nor courage, until the democratic changes set out here have been won (CP, 1982:81).

Hierdie verklaring adem die gees van die Westerse demokrasie en die idee van 'n regstaat wat na die Tweede Wêreldoorlog oor die hele Westerse wêreld ontwikkel het.

Daar is nie gepoog om aan die vryheidskonsep self 'n bepaalde teologies-etiese inhoud te gee nie. Die strategie wat ontwerp is om hierdie konsep in Suid-Afrika te verwerklik is egter duidelik teologieseties beredeneer. Die uitgangspunt in hierdie strategie is gestel in die latere bekende en invloedryke Kairosdokument (ICT, 1985:22). Hierdie uitgangspunt lui dat God aan die kant is van die armes en die standpunt word in die dokument begrond in Ps. 103:6. Op grond van hierdie standpunt word dan gesê:

As far as the present crisis is concerned, there is only one way forward to Church unity and that is for those Christians who find themselves on the side of the oppressor or sitting on the fence, to cross over to the other side to be united in faith and action with those 
who are oppressed. Unity and reconciliation within the Church itself is only possible around God and Jesus Christ who are to be found on the side of the poor and the oppressed (ICT, 1985:22).

Christene word dan opgeroep om deel te hê aan die stryd om vryheid van die verdruktes en hierdie stryd kan gevoer word deur burgerlike ongehoorsaamheid.

In 'n opvolgdokument word die lyde en sterwe van Jesus beredeneer binne die konteks van politieke bevryding. Oor Hom word gesê:

Jesus was killed because in the name of God he sided with the poor and the oppressed and opposed their oppressors. Jesus stood with the people in their sufferings and therefore he himself was made to suffer. He himself became a victim of oppression. He was killed, violently and mercilessly, because he took a stand against the forces of evil in his society at that time (ICT, 1986:5).

Deelname van Christene en kerke in Suid-Afrika aan die struggle, insluitende die gewapende stryd, is aangemoedig en gelegitimeer op grond van Skrifgedeeltes soos Jesaja 52:13-53:12; Klaagliedere 3:1-18 en 5:1-22; Job 21:1-12, 34; Jeremia 7:23-28; Lukas 22:47-53, 61-71; 23:1-5, 13-14, 20-24, 33-38, 44-46; Johannes 18:1-19:18; 1 Korintiërs 1:17-31, Hebreërs 12:1-4; Openbaring 13:1-10 (ICT, 1986:8). Hoewel Millard (1994:288) die Kairosdokument tipeer as 'n Christelike, Bybelse en teologiese kommentaar op die politieke krisis van daardie tyd in SuidAfrika, lê hierin, soos die geval was met die vryheidsbeskouings van Kruger in 1899 en apartheid sedert 1948, ook bepaalde voorveronderstellings wat die uiteindelike teologies-etiese perspektiewe bepaal.

Hierdie voorveronderstellings spruit uit die populêre Teologie van Bevryding van die sewentiger- en tagtigerdekades wat sterk gesteun het op die Filosofie van Bevryding wat na die Tweede Wêreldoorlog in die Westerse wêreld posgevat het. Om dié filosofie te verstaan moet kortliks gelet word op uitgangspunte van Bloch en Marcuse in hulle onderskeie samelewingsanalises en strategieë van veranderinge. 4

Bloch se siening oor die noodsaak van voortdurende maatskaplike verandering is, onder meer, gebou op sy bekende stelling: "wat is, kan nie waar wees nie" (Bloch, 1961:65). Hiermee het hy bedoel dat die

4 Die invloed van die Filosofie van Bevryding in die Teologie van Bevryding en die deurwerking daarvan in die moderne ekumeniese beweging is breedvoerig uitgewerk in Vorster (1981:203). Die konkretisering van die idees binne die Suid-Afrikaanse kerklike lewe in die sewentiger- en vroeg tagtigerjare in Suid-Afrika is uitgewerk in Vorster (1984:36). Slegs die hooflyne van hierdie strominge word in dié artikel weer aan die orde gestel. 
werklikheid nooit 'n afgehandelde werklikheid kan wees nie. Alles moet aan voortdurende verandering onderhewig wees. Toegepas op die maatskaplike orde beteken dit dat die status quo nooit voldoende kan wees nie. Daar moet voortdurende maatskaplike verandering wees, want dit is die realiteit van die menslike bestaan (Bloch, 1970:1-9). 'n Positiewe gevolg van hierdie maatskaplike verandering is dat die proses hoop gee aan die noodlydendes en verdruktes. Hulle kan hulle hoop op vryheid vestig en op die vervulling van die onvoltooide werklikheid.

Volgens Bloch (1961:115) lê hierdie veranderingsmotief ook diep gewortel in die Eksodusmotief in die Bybel. God is die Eksodusgod wat alles verander. Die Bybel predik ook sosiale verandering en vir hierdie standpunt beroep hy hom op tekste soos Jesaja 5:17 en Openbaring 21:4. Die verandering gee aan die mens hoop en waar hoop is, is religie (Bloch, 1970a:9-15; sien ook Bloch, 1970b). Die konsekwensie van Bloch se standpunt is dat die mens voortdurend krities ingestel moet wees teen die status quo waarin hy leef. Die mens kan hom nooit met die bestaande orde identifiseer nie. Hy moet altyd verandering soek en bevorder sodat hoop uit hierdie veranderingsproses gebore kan word.

Die filosofie van Bloch het wye invloed uitgeoefen op die maatskappykritiese studente-aktivisme van die laat-sestigerjare en in die kontrakultuur wat onder die jeug ontwikkel het (Duvenage, 1973:442; Roszak, 1969:84). Maar die invloed was veral sterk in die opkomende neoMarxisme van Marcuse waarin vryheid en bevryding vanuit hierdie perspektief beredeneer is. Met 'n beroep op Marx, Bloch en die psigoanalise van Freud het Marcuse die toenmalige Westerse en Kommunistiese samelewings beskou as eendimensionele samelewings wat in hulle wese totalitêr en onderdrukkend was. In hierdie samelewings is die mens geheel en al verkneg - hy leef nie, hy word geleef (Marcuse, 1968:7; 17, 149; Marcuse \& Popper, 1971:10, 21, 90 en Marcuse, 1971).

Heil en hoop vir die mens lê in totale bevryding van hierdie verknegtende samelewing. Die mens moet bevry word van die verknegting en die daaruit voortvloeiende leed en vernietigingsdrif. Hiervoor het Marcuse 'n etiek van bevryding uitgewerk (vgl. Vorster, 1981:227). Die kernmoment van hierdie etiek is die radikale en rewolusionêre verandering van die sosiale stukture. "Qualitative change is a change of the system as a whole" (vgl. Marcuse, 1970:90). Bevryding is daarom vir Marcuse 'n konkrete, fisiese, strukturele bevryding wat die totale onverwerping van die sosiale orde impliseer (Marcuse \& Popper, 1971:19). Verset is die wagwoord. Die groot verset teen die stagnante struktuur, dus die bestaande wet en orde, karakteriseer sy hele betoog oor vryheid. Verset is 'n aktiewe anti-krag teen die bestaande, 'n duidelike nee om verder mee te werk aan 'n onderdrukkende sisteem. Om die verset te voltrek is 
enige metode geregverdig - ook geweld, omdat geweld eintlik net teengeweld is teen die verdrukkende sisteem.

In sy betoog oor vryheid het Marcuse geweld geromantiseer. Hy het legitimiteit verleen aan burgerlike verset en gewelddadige aksies wat gerig was op die omverwerping van 'n politieke sisteem. Hiermee het hy 'n morele basis gegee aan terroriste-aksies wat in daardie tyd veral teen Westers-georiënteerde owerhede gevoer is. Die strategie van bevryding is eers deur die Swart Teologie, die Teologie van Rewolusie en later deur die Teologie van Bevryding in Christelik teologiese-etiese taal vertaal en as die Christelike strategie vir bevryding van verdruktes voorgehou. Hierin het teoloë soos Shaull (1969:190); Sölle (1965:159); Castro (1968:77); Gutierrez (1974:223); Cone (1978:75) 'n bydrae gelewer. Hierdie etiek van bevryding het die grondslag geword van die Wêreldraad se "Programme to combat rascism" (Vorster, 1981:264) en vandaar is ook die strategie van bevryding van die Suid-Afrikaanse Raad van Kerke ontwikkel (Vorster, 1984:64).

Die teologies-etiese fundering van die strategie van vryheid het dus op hierdie wyse ook in Suid-Afrika posgevat. Opmerklik is die ooreenkoms in die beredenering van vryheid deur Paul Kruger in 1899 en Tutu in 1976. Tutu (1976:15) sê die volgende: "The oppressed must be set free because God is the God of Exodus, the liberation God who is encountered in the Bible for the first time as the liberator striding forth with an outstretched arm to liberate the rabble of slaves, to turn them into people for his possession for the sake of all his creation". Albei het die Eksodusmotief gebruik om 'n teologies-etiese onderbou te gee vir hulle onderskeie sienings van vryheid vir die verdruktes - in Kruger se geval die Boere en in Tutu se geval die swart man. Die siening van Tutu is ook op wye vlak gehuldig deur die Teologie van Bevryding van daardie periode.

\section{Politieke vryheid in $\mathbf{2 0 0 0}$ en verder?}

Uit bogenoemde beredenering is dit duidelik dat die belangrikste vryheidskonsepte in Suid-Afrika sedert 1899 diepgaande deur bepaalde teologies-etiese perspektiewe beïnvloed is. Op die vraag waarom die toepassing van die sogenaamde Christelike beginsels van vryheid soveel onderdrukking en geweld tot gevolg gehad het, kan soos volg geantwoord word: die foute van die verlede was nie daarin geleë dat teologies-etiese perspektiewe uitgewerk is nie, maar dat hierdie perspektiewe in die gevalle van 1899 en 1948 eensydig en geïsoleerd gedoen is sonder ekumeniese bewustheid. Hierdie isolasie het die kerke die prooi gemaak vir sekulêre rassistiese voorveronderstellings. Daar is nie gelet op wat Christene elders in die wêreld oor hierdie vryheidsbeskouings te 
sê gehad het nie. In die geval van 1994 is die voorveronderstellings op hulle beurt uitgewerk met die sekulêre Filosofie van Bevryding as uitgangspunt en is kritiek uit kerklike kringe wêreldwyd eweneens nie ter harte geneem nie.

Ten spyte van die historiese pendule tussen vryheid en onderdrukking sedert 1899 is hierdie kringloop na 1994 in beginsel deurbreek met die koms van volledige demokrasie in Suid-Afrika Dit blyk uit die feit dat die demokratiseringsproses van 1990-1994 - merkwaardig genoeg - nie volledig geloop het langs die lyne van óf die Apartheidsteologie óf die Teologie van Bevryding, soos elk op sy eie wyse teologies-eties getuig het nie. Langs die weg van onderhandelinge en konsensus is die konsep van 'n regstaat aanvaar waarin die elemente van die Freedom Charter ingebou is. Vryheid word aan alle onderdane verseker deur die toepassing van fundamentele regte onder die jurisdiksie van 'n konstitusionele hof. In die 1996 grondwet van die Republiek van Suid-Afrika (RSA, 1996:8) word vryheid gewaarborg waaronder die vryheid en sekerheid van die persoon, van godsdiensoortuiging en -mening (p. 8), van uitdrukking (p. 9), van assosiasie (p. 10), van beweging en verblyf (p. 10), van bedryf, beroep en professie (p. 10) en vryheid om kultuur, taal en godsdiens te onderhou (p. 16). Verskeie ander regte in die grondwet verskans ook ander gestaltes van vryheid.

Die nuwe grondwet van Suid-Afrika is 'n "nooit weer-grondwet" wat as 'n reaksie op 'n bepaalde sosio-politieke orde, by name apartheid geformuleer is. Die vraag wat nou gevra word, is in hoe 'n mate die grondwet daarin gaan slaag om vryhede te verseker. Kan vryheid vir een nie weer lei tot verdrukking vir ander nie? Minderheidsgroepe in SuidAfrika maak reeds gewag van nuwe diskriminasie wat uiting vind in regstellende aksie, die beweerde miskenning van die Afrikaanse taal en die bevoordeling van sekere groepe ten koste van ander.

Die tweede vraag is wat die rol van Christelike getuienis en spesifiek die Christelike kerke gaan wees om die grondwetlike beginsel van vryheid vir almal te laat seëvier? Teologies-etiese perspektiewe is steeds nodig en onvermydelik. Die kerk kan immers nie in ' $n$ vakuum bestaan nie. Dit sal ook nie in die toekoms in 'n vakuum bestaan nie. Die voordeel van die jaar 2000 en verder is egter dat die kerke mekaar, óór die sosiopolitieke geskiedenis se verdeeldheid, gevind het en meer as in die verlede in ekumeniese verband kan saamwerk ten einde gebalanseerde teologies-etiese perspektiewe daar te stel. Hiervan getuig 'n byeenkoms soos die Rustenburg berade van 1990 en 1999. Ekumeniese wisselwerking verlaag die potensiaal vir eensydige standpuntinnames vanuit bepaalde sosio-kulturele, ideologiese of etnosentristiese voorveronderstellings, soos met die drie groot vryheidsbeskouings sedert 1899 die 
geval was. Kerklike isolasie moet vermy word en gesonde interaksie moet in alle fassette van kerk-wees nagestreef word.

Die handhawing van vryheid vir almal gaan besondere roepingsterreine vir die kerk daarstel wat soos volg geformuleer kan word:

- Hoe kan die kerk bydra tot die vestiging van 'n etos van vryheid by die owerheid en onderdaan binne die konteks van 'n regstaat? Teologiesetiese navorsing hieroor blyk tans uiters noodsaaklik te wees.

- Kan die kerk en die teologiese etiek 'n bydrae lewer tot die juridiese interpretasie van sekere fundamentele menseregte ten einde vaste riglyne vir die toekoms daar te stel? Hieroor moet in die teologiese etiek besin word.

- Hoe moet die kerke omgaan met hulle erfenis in hierdie verband waarin in verskillende omstandighede op sogenaamde Bybelse gronde groot onreg goedgekeur is?

- Hoe moet kerke en Christene gestalte gee aan die Christelike leer van versoening in die konkrete situasie van Suid-Afrika in 2000 na 'n eeu van stryd, verdrukking en uitbuiting?

Hierdie vrae gaan Christene in Suid-Afrika besig hou in die onmiddelike toekoms.

\section{Bibliografie}

BANTON, M. 1970. The concept of rascism. (In Zubaida, S. Race and racialism. London : Tavistock. p. 1-31.)

BLOCH, E. 1961. Philosophische Grundvragen I. Zur Ontologie des Noch-nichtseins. Frankfurter am Main : Suhrkamp.

BLOCH, E. 1970a. A philosophy of the future. New York : Herder.

BLOCH, E. 1970b. Religion im Erbe. Eine Auswahl aus seinem religionphilosophischen Schriften. Hamburg : Siebenstern.

BOTHATEC, J. 1961. Calvin und das Recht. Vienna : Bohlhaus.

BURNS, A. 1948. Colour prejudice; with particular reference to the relationship between whites and negroes. London : Allen.

CALVYN kyk CALVIN

CALVIN, J. 1864. Commentary upon the epistle of Saint Paul to the Romans. Edinburgh : Calvin Translation Society.

CALVIN, J. 1957. Institutes of the Christian Religion. Translated by H. Beveridge. Grand Rapids : Eerdmans.

CASTRO, E. 1968. Bekering en sociale gedaanteverwisseling. (In Wereldraad van Kerke. Kerk en Revolutie, een bloemlesing uit de voorstudies voor de congres van de WRK over kerk en maatschappij. Baarn : Bosch \& Keuning. p. 77-81.)

COETZEE, J.C. 1965. Volk en Godsvolk in die Nuwe Testament. Potchefstroom : Pro Rege. 
CONE, J.H. 1975. De zwarte theologie en zwarte bevrijding. (In Moore, B. Zwarte theologie in Zuid-Afrika. Baarn : Ten Have. p. 1-25.)

CONGRESS OF THE PEOPLE. 1982. The freedom charter. (In De Braganca, A. \& Wallerstein, I. The African Liberation Reader. London : Zed. p. 81-87.)

$\mathrm{CP}$

kyk CONGRESS OF THE PEOPLE

CRONJE, G. 1946. Voogdyskap en apartheid. Pretoria : Van Schaik.

CUTHBERTSON, G.C. 1994. Christianity, imperialism and colonial warfare. (In Hofmeyr, J.W. \& Pillay, G.J. A history of Christianity in South Africa. Pretoria : HAUM Tertiary. p. 150-171.)

DE GRUCHY, J.W. 1979. The church struggle in South Africa. Grand Rapids : Eerdmans.

DE KLERK, P. 1969. Die geskiedbeskrywing oor Paul Kruger. Potchefstroom : PU vir CHO. (M.A.-verhandeling.)

DU PLESSIS, H. 1963. 'n Banier vir die volke. Die Woord van God in en vir die wêreld. Potchefstroom : Pro Rege.

DU TOIT, J.D. 1977. Totius. Versamelde werke. volume 7. Kaapstad : Tafelberg.

DUVENAGE, S.C.W. 1973. Die opstandige student, 'n evaluering en analise van studenteaktivisme in die VSA. Potchefstroom : PU vir CHO. (D.Phil.-proefskrif.)

EYBERS, G.W. 1918. Select constitutional documents illustrating South African history. London : Dutton.

GUTIERREZ, G. 1974. A spirituality of liberation. (In KEE. A. A reader in political theology. London : SCM.)

ICT

kyk INSTITUTE FOR CONTEXTUAL THEOLOGY

INSTITUTE FOR CONTEXTUAL THEOLOGY. 1985. The Kairos document. Challenge to the church. Braamfontein : ICT.

INSTITUTE FOR CONTEXTUAL THEOLOGY. 1986. The Kairos liturgies. Braamfontein : ICT.

KENNEY, H. (Henry). 1980. Architect of apartheid. H.F. Verwoerd - An appraisal. Johannesburg: Ball.

KINGHORN, J. 1986. Die N.G. Kerk en apartheid. Johannesburg : MacMillan.

KRUGER, S.J.P. 1952a. Antwoord van president S.J.P. Kruger op versoekskrifte deur burgers van die Zuid-Afrikaansche Republiek aan hom gerig om hom vir die tweede keer as staatspresident verkiesbaar te stel en wel in die verkiesing wat in 1888 gehou sou word. (In Du Plessis, J.S. President Kruger aan die woord. Bloemfontein : Sacum. p. 30-32.)

KRUGER, S.J.P. 1952b. Toespraak gehou op 16 Desember 1896 by die geleentheid van die staatsfees te Paardekraal. (In Du Plessis, J.S. President Kruger aan die woord. Bloemfontein : Sacum. p. 36-41.)

MALAN, D.F. 1964a. Politieke testament. (In Pienaar, S.W. Glo in u volk. Dr. D.F. as redenaar 1908-1954. Kaapstad : Tafelberg. p. 84-89.)

MALAN, D.F. 1964b. Die onafhanklikheid van Suid-Afrika. (In Pienaar, S.W. Glo in u volk. Dr. D.F. as redenaar 1908-1954. Kaapstad: Tafelberg. p. 19-36.)

MALAN, D.F. 1964c. Aan almal wat ons volk liefhet. (In Pienaar, S.W. Glo in u volk. Dr. D.F. as redenaar 1908-1954. Kaapstad : Tafelberg. p. 250-252.)

MALAN, D.F. 1964d. Die nuwe regering. (In Pienaar, S.W. Glo in u volk. Dr. D.F. as redenaar 1908-1954. Kaapstad : Tafelberg. p. 241-243.)

MALAN, D.F. 1964e. Bloedrivier. (In Pienaar, S.W. Glo in u volk. Dr. D.F. as redenaar 1908-1954. Kaapstad : Tafelberg. p. 121-130.)

MARCUSE, H. 1968. Eros en cultuur. Utrecht : Bijleveld. 
MARCUSE, H. 1970. Liberation from the affluent society. (In Hamalian, L.\& Rederick, K.R. The radical vision, essays for the seventies. New York : City College. p. 128.)

MARCUSE, H. \& POPPER, K. 1971. Sociale revolutie/sociale hervorming, een confrontatie. Baarn : Wereldvenster.

MARCUSE, H. 1971. De eendimensionele mens; studies over de ideologie van de hoogs industriële samenleving. Bussum : Brand.

MILLARD, J. 1994. Christianity in South Africa since 1948. (In Hofmeyr, J.W. \& Pillay, G.J., eds. A history of Christianity in South Africa. Pretoria : HAUM Tertiary. p. 251-299.)

NIEUWOUDT, C.F. 1966. Die konstitusies van die Vrystaat- en Transvaalse republieke. (In Van Jaarsveld, F.A. \& Scholtz, G.D. Die Republiek van SuidAfrika, agtergrond, ontstaan en toekoms. Johannesburg : Voortrekkerpers. p. 71-90.)

REPUBLIEK VAN SUID-AFRIKA., 1996. Grondwet van die Republiek van SuidAfrika. Pretoria : Staatsdrukker.

ROMPEL, F. 1902. Gedenkschriften van Paul Kruger, geciteerd aan H.C. Bredell en Piet Grobler. s'Gravenhage : Nijhoff.

ROSZAK, T. 1969. The making of a counter culture, reflections on the ethnocratic RSA society and its youthful opposition. New York : Double Day.

kyk REPUBLIEK VAN SUID-AFRIKA

SHAULL, R. 1969. Uitdaging aan kerk en maatschappij. Baarn : Wereldvenster.

SNYMAN, W.J. 1977. Nuwe en ou dinge. Potchefstroom : Pro Rege.

SÖLLE, D. 1965. Plaatsbekleding. Amsterdam : Ten Have.

STEYN, M.T. 1953. Laaste toespraak, Volksraad 1899. (In Oberholster, J.J. \& Van Schoor, M.C.E. President Steyn aan die woord. Bloemfontein : Sacum. p. 8389.)

TREURNICHT, A.P. 1975. Credo van 'n Afrikaner. Kaapstad : Tafelberg.

TUTU, D. 1976. Letter to the Prime Minister. Ecunews, 17: 10, May 26.

VAN DER VYVER, J.D. 1975. Die beskerming van menseregte in Suid-Afrika. Kaapstad : Juta.

VAN WYK, J.H. 1993. Homo Dei. 'n Prinsipiële besinning oor enkele mensbeskouings, waaronder dié van Calvyn. In die Skriflig, 27 (Supplementum).

VERWOERD, H.F. 1963. Deelname aan die debat oor die wetsontwerp ter bevordering van Bantoe-selfbestuur, Volksraad, 20 Mei 1959. (In Pelser, A.N. Verwoerd aan die woord. Johannesburg : Afrikaanse Pers Boekhandel. p. 154275.)

VILLA-VICENCIO, C. 1988. Trapped in apartheid. A socio-theological study of the English speaking churches. New York : Orbis.

VIVIER, J.M. 1970. Die presidentsverkiesing van 1893 in die Zuid-Afrikaansche Republiek. Potchefstroom : PU vir CHO. (MA verhandeling.)

VORSTER, J.M. 1981. Kerk en die kleurvraagstuk vandag. Johannesburg : De Jongh.

VORSTER, J.M. 1984. Die Neo-Marxistiese Politieke Teologie in Suid-Afrika. Potchefstroom : $\mathrm{PU}$ vir $\mathrm{CHO}$.

VORSTER, J.M. 1998. Die Belharbelydenis in dogma-historiese prespektief. In die Skriflig, 32(4):469-486.

VORSTER, J.M. 1999. Calvin and Human Rights. The Ecumenical Review, 51(2):209-220.

WAARHEIDS- EN VERSOENINGSKOMMISSIE. 1998. Verslag. Kaapstad : Juta. 
WALKER, W. 1992. A history of the christian church. Edinburgh : Clark.

WITTE, J. 1996. Moderate religious liberty in the theology of John Calvin. Calvin WVK

Theological Journal, 31(2):359-403.

ZAR

kyk WAARHEIDS EN VERSOENINGSKOMISSIE

kyk ZUID-AFRIKAANSCHE REPUBLIEK

ZUID-AFRIKAANSCHE REPUBLIEK. 1918. Grondwet van de Zuid-Afrikaansche Republiek. (In EYBERS, G.W. Select constitutional documents illustrating South African history. London : Dutton. p. 363-409.)

\section{Kernbegrippe:}

apartheidsgemeenskap

bevrydingstryd

Eksodus-motief

menseregte

politieke vryheid - weersprekende konsepte van

regstaat

vryheid - teologies-etiese vooronderstellings

\section{Key concepts:}

apartheid society

constitutional state

Exodus-motif

freedom - theological-ethical presuppositions

human rights

liberation struggle

political freedom - conflicting concepts of 